\title{
Role of Aleyrodidae Entomophages in agrobiocenosis in type content and management in Uzbekistan
}

\author{
Otabek Sulaymonov ${ }^{1,{ }^{*}}$ and Azimjan Anorbaev ${ }^{2}$ \\ ${ }^{1}$ Scientific Research Institute of Plant Quarantine, Tashkent, Uzbekistan \\ ${ }^{2}$ Tashkent State Agrarian University, University str., 2, Tashkent province, Uzbekistan, 100140
}

\begin{abstract}
This article identified the entomophagous species that are constantly feeding on alfalfa, and identified 27 species of entomophagous predominant species belonging to 7 families of entomophagous species of alfalfa pests. It was observed that these are the families Neuroptera, Aphelinidae, Syrphidae, Coccinellidae, Anthocoridae, Nabidae and, Miridae. According to the ratio of entomophages, the most populous families were identified as goldflies (Shrysopidae), khan beetles (Coccinellidae), and wild caterpillars (Miridae). Their populations formed diversity. Studies have been conducted on the use of parasite encarcation parasites in the management of whitefly population. It has been used in a variety of consumption norms against leachate in open and closed conditions. Encarsia (Encarsia partinopea Masi) was used to control the amount of whitefly (Trialeurodes vaporariorum) in greenhouse conditions. In the greenhouse conditions, $87.9 \%$ biological efficiency was achieved on day 28 after the application of encarcation in a 1:10 ratio in cucumber crops, and by the end of the season, parasitic entomophages were effectively controlling the amount of whiteflies. After 24 days of application in a 1:10 ratio in cucumbers planted in the open, the biological efficiency reached $83.5 \%$. At 30 days after application, $86.5 \%$ biological efficacy was maintained.
\end{abstract}

\section{Introduction}

Currently, there are 1,156 species of insects belonging to the family Aleyrodidae (whites) on Earth, according to Martin \& Mound (1987). Later in the study of insects belonging to the family Aleyrodidae (Hemiptera) notes that there are 166 families, 1551 species belonging to 3 subfamilies (Aleurodicinae, Aleyrodinae and Udamosellinae) [1, 2]. They have shown that their morphological aspect is of great importance in distinguishing white species from one another. It is believed that the development of insects belonging to the whitefly family differs from each other in the transition from the fourth stage to the sponge during the nymph $[1,3]$.

\footnotetext{
* Corresponding author: o.a.sulaymonov@yandex.com
} 
There are more than 70 cousins in the wild, not all of them are specialized. But some species feed only on one species of pest. Of the predatory entomophagous, goldflies (Shrysopidae), wild caterpillars (Miridae), beetles (Coccinellidae), and wild canals (Acaria) are relatively effective. But from the wild shackles, Macrolophus nibulis and other species control the amount of whiteflies to a certain extent $[4,5]$.

According to S.E. Naranjo's research [6], the degree to which the amount of whitefly's external natural relatives controls their quantity depends more on the type of crop in which the whitefly is fed. Some researchers have suggested that studies on systematic analysis and evaluation of wild entomophagous whitefly in the management of whitefly are insufficient [6-8].

At present, 150 species of wild entomophagous cotton bollworm have been identified in China alone, and only a few species have been identified for their biological properties. Subsequently, 7 new species of entomophagous species were identified, of which 2 species belonged to the Coccinelidae family, 4 species to the Heteroptera family and 1 species to the Diptera family, 14 species to Gerling and others [2]. 16 species of B. tabaci cousins were identified as belonging to the female beetle family as predatory entomophagous $[3,9]$.

In Uzbekistan, 4 species of phytophagous members of the family Alerodoidae cause serious damage to agricultural crops. Although the biological properties of this pest and its damage to agricultural crops, entomophagous have been studied by several scientists, the lack of effective methods and tools to control the amount of this pest requires further research on this pest $[1,10]$.

This pest is strongly damaging crops in greenhouses. Eggplant and tomato crops are seriously damaged due to the fact that the greenhouse whitefly forms a large population in open field crops and later prefers crops belonging to the tomato family. It was found that this pest began to damage agricultural crops in the 70 s of the 20 th century and began to lose a certain part of the crop $[1,7]$.

It has also been found that the pest grows well in the squash family, cotton and citrus crops, and has led to the loss of a large part of the yield of these crop species [2]. According to Duffus and other scientists, more viral diseases are observed in crops infested with whitefly. In addition, whiteflies develop in different populations according to the type of agricultural crop $[5,8]$.

Despite the use of a series of chemicals in some greenhouses, the fact that this pest quickly recovers its population shows that it has developed resistance to chemicals. Another effective way to manage the amount of greenhouse whitefly is to use these biological agents. In the biocenosis of the pest there are more than 60 species of entomophagous members of the family Aphelinidae, Anthocoridae, Miridae, Coccinellidae, and Neuroptera, but there are relatively few specialized species of economic importance [6]. Thus, it is important to study the types of entomophagous, the interaction of parasite-hosts in agrobiocenosis, and the possibility of using entomophagous in the management of phytophagous quantities as investigated in this paper.

\section{Materials and methods}

In order to identify entomophagous species of greenhouse whitefly in the conditions of Uzbekistan and to apply their capabilities in the management of pest numbers, we conducted observations in 2014-2016.

The research was conducted in the agrobiocenosis of vegetables and melons in Tashkent, Syrdarya and Andijan provinces. The crop was carried out on crops such as tomatoes, eggplant, cucumbers and melons. MBS-2 during the experiment; MBI-3; electron microscope Telsa-BS-613 (Czech) from microscopes; thermostat MEMMERT E05273 and other entomological instruments were used. Reproduction and storage of entomophagous 
during the dormancy period was carried out in accordance with the guidelines of $\mathrm{KH}$. Kimsanbaev [1]. Systematic analysis of entomophagous species collected from field conditions, determination of species composition using the methods of B. P. Adashkevich [8]. The entomophages caught in the "Opredelitel" experiment were carried out according to the methods of V. S. Velikan $[1,8]$.

In order to study the entomophagous species of greenhouse whitefly, vegetable and melon crops in the open fields were continuously observed during 2019-2020, and were carried out in areas strongly affected by greenhouse whitefly. Entomophages collected during the observations were sent to the laboratory. Next, most of the identified entomophages were found to be wild entomophagous. In nature, the majority of entomophagous species are homozygous, they are more common in tomato agrobiocenosis because of the compatibility of plant species and climatic conditions, as well as the richness of this agrobiocenosis entomofauna. In addition to whitefly, there were more than 10 species of pests (cotton moth, arbona moth, autumn moth, gamma moth, poppy flies, melon whitefly, rust mite) and they also caused significant damage. There are a number of entomophagous species that feed on whitefly in our country, but to date they have not been systematically analyzed. Therefore, entomophagous species of whitefly were studied in the agrobiocenoses of Tashkent, Syrdarya and Andijan provinces of the country.

The studies were conducted in a field of tomatoes and sunflowers infested with alfalfa in open field conditions. In 3 ha of tomatoes and 2 ha of sunflower and cucumbers, melons, cotton, and bean fields, agrobiocenosis were studied as experimental areas. The studies continued from the beginning to the end of the crop season, with each identified and collected sample systematically analyzed under laboratory conditions. The incidence rate and population size of all entomophagous species encountered in agrobiocenosis, relative to whitefly, were studied.

The provinceal occurrence of entomophagous species was also studied. Observations in the agrobiocenosis of the Tashkent and Syrdarya provinces of the country revealed a large number of entomophagous species and a variety of entomophagous parasites. However, given the breadth of the species composition, the species composition of the pest parasites was also identified during the study.

The stepwise propagation method is effective in the cultivation of encarsia in the laboratory, and tobacco seedlings were planted. The plant behaved and was infested with aphids after forming 4 - 5 petals. Mature whiteflies gather on the lower leaves of the plant and begin to lay eggs. A week later, with the appearance of larvae on the leaves were infested with enkarsia. By this time, between 1,000 and 2,000 first-year whitefish larvae had appeared on each tobacco leaf. Infestation of larvae with encarcia was carried out with the emergence of leaves, which are enkarsia fungi, between the plant horns. By this time, the larvae of the first year of life have matured and passed on to the second year. Encapsulation is usually distributed in a ratio of 1: 5 according to the number. In 7-8 days in the larvae of whiteflies appeared fungi of enkarsia. When the occurrence of such fungi on tobacco leaves reached $70 \%$, the collection of enkarsia was started.

To increase the encarcation in this way, the temperature should be $+27 \mathrm{oS}$ and the length of the day should be 15 - 16 hours. A "malyutka" washing machine can be used to separate the encarsia sponges from the harvested tobacco leaves.

In this case, the machine is first poured warm water and $15-20$ medium-sized leaves are cut into small pieces. Close the lid and turn for $2-3$ minutes. Then he stopped the car and removed the leaves. In this case, the encarcia fungi separated from the leaf remain on the surface of the water. Undamaged whitefly larvae drown.

The sponges that stuck to the walls of the car and fell under the car were washed with cold water and caught with a sieve. In greenhouses, tobacco seedlings were planted in 
separate sections, 40 - 50 days apart. As a result, continuous cultivation of enkarsia was ensured.

\section{Results and discussion}

According to our data, the main parasite-predator-host species composition of agrobiocenosis and their food specialization were determined (Table 1). According to the data collected, 27 species of predatory and parasitic entomophagous species belonging to 7 families of entomophagous species of whiteflies were identified. These are Chrysopa carnea Steph, Chrysopa septempunctata Wesm, Chrysopa formosa Br, Chrysopa dubitans McLoria, Encarsia partinope, Encarsia partinope of the families Neuroptera; Aphelinidae, Syrphidae, Coccinellidae, Anthocoridae, Nabidae, Miridae rueppelli Wied, Sphaerophoria philanthus Mg, Syrphus ribesii L, Metasyrphus luniger Mg, Coccinella septempunctata, Coccinella undecimpunctata, Adonia variegata, Adonia variegata, Scymnus frontalier, Stethorus punctillum, Scymnus rubromaculatus, Coccinula quatuordecimpustulata; the Propylaea quatuordecimpunctata, Orius Niger Wolf, Nabil turquoise L; representatives of Campylomma diversicornis Reuter, and Campylomma verbasci Meyer-Dür were registered. The food specialization of the above-mentioned family members is mainly the eggs, larvae, nymphs, and mature adult imagos of the aquatic.

In the study of Trialeurodes vaporariorum, Bemisia tabaci, and Dialeurodes citri species of whitefly, the formation of their relationship on the parasite-host and predatorcousin in different agrobiocenoses, their mutual ratios were observed. Of the identified entomophagous species, there are species that specialize in whitefly phytophagous and whitefly species.

Table 1. Entomophagous species composition and occurrence rates of whitefly species in agrobiocenosis (Tashkent, Syrdarya, and Andijan provinces, 2019-2020)

\begin{tabular}{|c|c|c|c|c|}
\hline \# & $\begin{array}{c}\text { Types of } \\
\text { entomophagous }\end{array}$ & Species & Nutrition source & Appearance \\
\hline \multicolumn{5}{|c|}{ Neuropteran family } \\
\hline 1 & Chrysopa carnea Steph. & $\begin{array}{c}\text { Trialeurodes } \\
\text { vaporariorum, } \\
\text { Bemisia tabaci, } \\
\text { Dialeurodes citri }\end{array}$ & $\begin{array}{l}\text { Imago, larva, egg, } \\
\text { nymph }\end{array}$ & +++ \\
\hline 2 & $\begin{array}{c}\text { Chrysopa septempunctata } \\
\text { Wesm. }\end{array}$ & $-/ /-$ & $-/ /-$ & +++ \\
\hline 3 & Chrysopa formosa $\mathrm{Br}$. & $-/ /-$ & $-/ /-$ & ++ \\
\hline 4 & Chrysopa dubitans McL. & $-/ /-$ & $-1 / /-$ & + \\
\hline \multicolumn{5}{|c|}{ Aphelinidae family } \\
\hline 5 & $\begin{array}{c}\text { Encarsia partinopea } \\
\text { Masi. }\end{array}$ & $\begin{array}{c}\text { Trialeurodes } \\
\text { vaporariorum, } \\
\text { Bemisia tabaci, } \\
\text { Dialeurodes citri }\end{array}$ & $\begin{array}{l}\text { 3-4 year-old } \\
\text { nymph }\end{array}$ & ++ \\
\hline 6 & Encarsia formosa Gah. & $-/ /-$ & $-1 /-$ & +++ \\
\hline 7 & Eretmocerus mudus Merc. & $-/ /-$ & $-/ /-$ & + \\
\hline 8 & Encarsia tricolor Forst. & $-/ /-$ & $-/ /-$ & + \\
\hline \multicolumn{5}{|c|}{ Syrphidae family } \\
\hline 9 & $\begin{array}{c}\text { Sphaerophoria rueppelli } \\
\text { Wied. }\end{array}$ & $\begin{array}{c}\text { Trialeurodes } \\
\text { vaporariorum, } \\
\text { Bemisia tabaci }\end{array}$ & $\begin{array}{l}\text { Imago, larva, egg, } \\
\text { nymph }\end{array}$ & ++ \\
\hline 10 & $\begin{array}{l}\text { Sphaerophoria philanthus } \\
\text { Mg. }\end{array}$ & $-/ /-$ & $-/ /-$ & +++ \\
\hline
\end{tabular}




\begin{tabular}{|c|c|c|c|c|}
\hline 11 & Syrphus ribesii L. & $-/ /-$ & $-/ /-$ & +++ \\
\hline 12 & Metasyrphus luniger $\mathrm{Mg}$. & $-/ /-$ & $-/ /-$ & + \\
\hline \multicolumn{5}{|c|}{ Coccinellidae family } \\
\hline 13 & $\begin{array}{c}\text { Coccinella } \\
\text { septempunctata }\end{array}$ & $\begin{array}{c}\text { Trialeurodes } \\
\text { vaporariorum, } \\
\text { Bemisia tabaci }\end{array}$ & $\begin{array}{l}\text { Imago, larva, egg, } \\
\text { nymph }\end{array}$ & +++ \\
\hline 14 & $\begin{array}{c}\text { Coccinella } \\
\text { undecimpunctata }\end{array}$ & $-/ /-$ & $-/ /-$ & +++ \\
\hline 15 & Adonia variegata & $-/ /-$ & $-/ /-$ & +++ \\
\hline 16 & Adonia variegata & $-/ /-$ & $-/ /-$ & + \\
\hline 17 & Scymnus frontalis & $-/ /-$ & $-/ /-$ & ++ \\
\hline 18 & Stethorus punctillum & $-/ /-$ & $-/ /-$ & + \\
\hline 19 & Scymnus rubromaculatus & $-/ /-$ & $-/ /-$ & +++ \\
\hline 20 & $\begin{array}{c}\text { Coccinula } \\
\text { quatuordecimpustulata }\end{array}$ & $-/ /-$ & $-/ /-$ & ++ \\
\hline 21 & $\begin{array}{c}\text { Propylaea } \\
\text { quatuordecimpunctata }\end{array}$ & $-/ /-$ & $-/ /-$ & + \\
\hline \multicolumn{5}{|c|}{ Anthocoridae family } \\
\hline 22 & Orius niger Wolf. & $\begin{array}{c}\text { Trialeurodes } \\
\text { vaporariorum, } \\
\text { Bemisia tabaci }\end{array}$ & $\begin{array}{l}\text { Imago, larva, egg, } \\
\text { nymph }\end{array}$ & ++ \\
\hline \multicolumn{5}{|c|}{ Nabidae family } \\
\hline 23 & Nabis ferus $\mathrm{L}$. & $\begin{array}{c}\text { Trialeurodes } \\
\text { vaporariorum, } \\
\text { Bemisia tabaci }\end{array}$ & $\begin{array}{l}\text { Imago, larva, egg, } \\
\text { nymph }\end{array}$ & ++ \\
\hline \multicolumn{5}{|c|}{ Miridae family } \\
\hline 24 & $\begin{array}{c}\text { Campylomma } \\
\text { diversicornis } \text { Reuter }\end{array}$ & $\begin{array}{c}\text { Trialeurodes } \\
\text { vaporariorum, } \\
\text { Bemisia tabaci }\end{array}$ & $\begin{array}{l}\text { Imago, larva, egg, } \\
\text { nymph }\end{array}$ & ++ \\
\hline 25 & $\begin{array}{c}\text { Campylomma } \\
\text { verbasci Meyer-Dür. }\end{array}$ & $-/ /-$ & $-/ /-$ & + \\
\hline \multicolumn{5}{|c|}{ Phytoseiidae family } \\
\hline 26 & Metaseiulus occidentalis & $\begin{array}{c}\text { Trialeurodes } \\
\text { vaporariorum, } \\
\text { Bemisia tabaci }\end{array}$ & $\begin{array}{l}\text { Imago, larva, egg, } \\
\text { nymph }\end{array}$ & +++ \\
\hline 27 & Phytoseius rubii & $-/ /-$ & $-/ /-$ & + \\
\hline
\end{tabular}

Note: $($ low $)+\ldots+++$ (high)

In the biocenosis, the insect parasite-host relationship is maintained. This is because if a parasite or host relationship is broken in them, a species can proliferate or disappear altogether. The identified entomophagous species were collected on the basis of agrobiocenoses of Kibray, Zangiota, and Yangiyul districts of Tashkent province. The diversity of entomophagous species collected in Tashkent province was higher than the entomofauna of agrobiocenosis of Syrdarya province. The most common predators were the female beetle and the semi-hardy beetle. 
Entomophagous species of alfalfa controlled their quantity to some extent, but in some agrobiocenoses, depending on the type of crop, it can be seen that alfalfa populations have increased dramatically. The encounter rates of entomophagous were also analyzed.

Changes in the environment and ecological processes are drastically reducing crop yields. It is important to meet the food needs of the population of our country and ensure the environmental safety of these products. One of the most harmful pests in the cultivation of tomato and cucumber crops in the open and indoor conditions in the vegetable growing areas of the country is greenhouse whitefly (T. vaporariorum), in some fields up to 7-8 times chemicals are used. These chemicals, firstly, poison people and soil, and secondly, pose a serious economic problem for entrepreneurs.

Entomophagous species that are relatively abundant in whitefly belong to the goldeneyed family: (Shrysopidae) Shrysopa carnea Steph, Shrysopa formosa Br; from the family of beetle beetles: (Coccinellidae) Coccinella septempunctata LIN, wild caterpillars (Miridae) Macrolophus nubilus, parasite Enkarsia (Aphelinidae) Encarsia formosa Gah, Encarsia partenopea Masi, and Eretmocerus ycasecea Metaceae.

When the population densities of these entomophages were studied, it was found that their differences were large. In this case, the development of wild entomophagous from the sowing period (April) to the end of the vigil period (October) was observed. Some species of these entomophagous species have also been specialized, in which wild macrolophus caterpillars and wild whiteflies feed on more white larvae. Even when these species were propagated under laboratory conditions, they were fed with 2-3-year-old larvae of whitefly. The parasite entomophagous is relatively rare and the most populous species, Encarsia formosa, has been found.

According to the study, the relatively common Shrysopidae family had a high population density of $21.2 \%$ on average, Coccinellidae was found to be $24.5 \%$, the sevenpointed type was relatively common in this family, and the Miridae family members were $26.4 \%$ on entomophagous. Aphelinidae were found to be an average of $16.2 \%$ of this family, a relatively common species of enkarsia formosa, while a representative of the Phytoseiidae family of wild canes was found to be $11.7 \%$, a smaller number than other species. In addition to these encountered species, other species of entomophagous were also encountered but most were found to be omnivorous. The population density of these entomophages was low relative to the greenhouse alfalfa population, and they were found to be unable to control the pest rate by averaging 22:1 for all entomophagous and alfalfa (larvae and imagoes) pest-entomophagous (Figure 1). In doing so, they are advised to use additional parasites and predatory entomophagous. We are learning about this in my next research. 


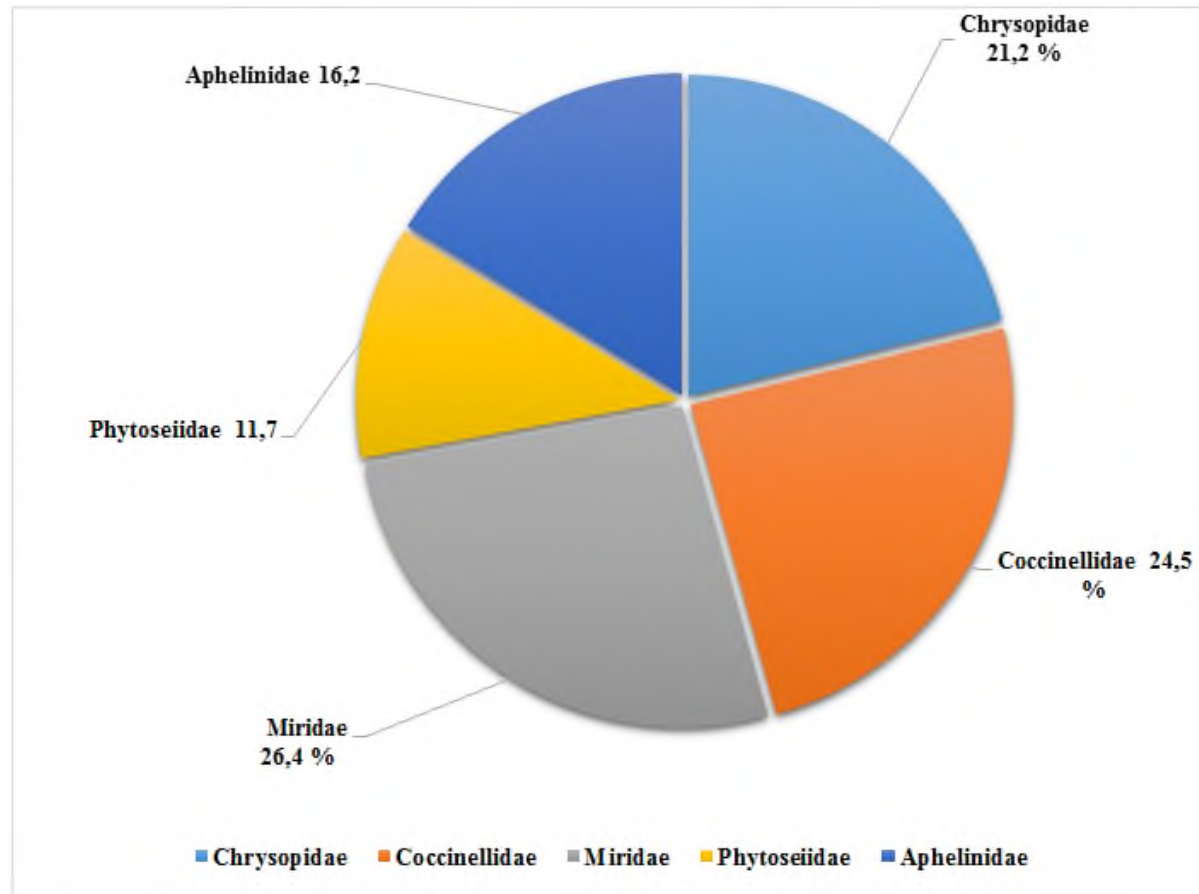

Fig. 1. Interrelation of entomophagous species of greenhouse whitefly in tomato agrobiocenosis (Tashkent, Syrdarya, and Andijan provinces, 2019-2020)

In the agrobiocenosis of tomatoes and cucumbers in Tashkent and Andijan provinces, the main and most common species of alfalfa and its entomophagous species were analyzed, which were more common than other species in the family Aphelinidae.

Among the factors that to some extent control the development of organelles in agrobiocenosis are these species of entomophagous, there are several species of entomophagous, but not all of them are effective. Two species of the Aphelinidae family, $E$. partenopea and Eretmocerus mundus, which specialize in whitefly from entomophages, are more productive than other species $[1,2]$.

In Central Asian countries, a simple encarcation known as trichoporus - E partenopea Masi is very effective against greenhouse whiteflies. This insect is a parasite of various whiteflies in greenhouses and open fields. E partenopea Masi type has a significant advantage over encarcation formosa ( $E$ formosa) because it is well adapted to the local, ecological environment [8].

We conducted research on the application of encarcation against greenhouse whitefly. The application of the parasite against the pest was carried out on a cucumber crop in the greenhouses of a small experimental farm of Tashkent State Agrarian University, Kibray district, Tashkent province. In this case, the average amount of greenhouse whitefly per leaf was determined. The air temperature was $25-26^{\circ} \mathrm{C}$, relative humidity was $67 \%$. According to him, it is possible to increase the efficiency of encarption due to the ability to control the air temperature and relative humidity in the greenhouse.

The average number of mature breeds of whiteflies per leaf was 35.9. The average number of larvae was 26.4 and the number of eggs was 12.8. In the laboratory, the multiplied encarcation was distributed in three variants, and the study determined the cost norm to control the amount of encarcation relative to the whitefly. 
Enkarsia (E partenopea) in mature species against whiteflies was distributed in ratios of $1: 10,1: 20$, and 1:30. The scheme of placing the parasite was carried out 3 times per $5 \times 5 \mathrm{~m}$. The chemical agent as a standard is Pilarclotrine $28 \%$ ZC. $(0.45 \mathrm{l} / \mathrm{ha})$ was obtained. Taking into account the presence of a chemical in the experiment, the results of the experiment were observed from day 3.

Experiments showed no efficacy in parasitized fields on day 3, but Pilarclotrin showed $80.9 \%$ biological efficacy in the area where $28 \%$ ZC was applied. One week after the parasite was released, parasitic colonies began to form but the number of pests did not decrease. We stopped the amount of pest but could not lower it. On day 7, the biological efficacy was $98.6 \%$ when Pilarclotrine $28 \%$ ZC was used. In the variant in which enkarsia was applied, the amount of alkali began to decrease on days 12-14, the biological efficiency was found to be $42.2 \%$ in the $1: 10$ ratio, $28.8 \%$ in the $1: 20$ ratio, and $11.6 \%$ in the $1: 30$ ratio. On day 14 , the biological efficacy was reduced to $76.9 \%$ in the reference variant (Pilarclotrine $28 \% \mathrm{ZC}$ ). At a 28-day rate of 1:10 after encarcation application, $87.9 \%$ biological efficiency was achieved, and by the end of the season, parasitic entomophagous efficacy was effectively managed.

In our next variant, the 21 -day biological efficiency was $57.0 \%$ when the whitefly was applied in a 1:20 ratio. On day 28, the biological efficiency of the mite parasite was $64.2 \%$ and controlled the amount of mite until the end of the season.

In our next variant, when the parasite host relationship was applied at a 1:30 ratio, the biological efficiency was slightly lower than the above options. In this variant, the biological efficiency was 21 days and was $44.7 \%$. On the 28th day, the figure was $51.7 \%$. Due to the low level of whitefly control in this variant, the amount of whitefly per leaf was on average 12.4 pieces by the end of the season (Table 2).

In our reference variant, the level of pest control was initially high, and then the population size of the pest was restored.

Table 2. Biological effectiveness of anti-whitefly in cucumber crops in the greenhouse (Andijan district of Andijan province, 2019-2020)

\begin{tabular}{|c|c|c|c|c|c|c|c|}
\hline \multirow[b]{2}{*}{ \# } & \multirow{2}{*}{ Options } & \multirow{2}{*}{$\begin{array}{c}\text { From the } \\
\text { application of } \\
\text { encarcation } \\
\text { number of } \\
\text { whitefly, pes }\end{array}$} & \multicolumn{5}{|c|}{ After applying Encarcia, pcs } \\
\hline & & & 3 days & 7 days & 14 days & 21 days & 28 days \\
\hline 1 & $\begin{array}{c}\text { Encarcia: } \\
\text { whitefly }(1: 10)\end{array}$ & 28.4 & 31.2 & 29.6 & 16.4 & 8.5 & 7.2 \\
\hline 2 & $\begin{array}{c}\text { Encarcia: } \\
\text { whitefly }(1: 20)\end{array}$ & 26.3 & 33.5 & 25.8 & 18.7 & 11.3 & 9.4 \\
\hline 3 & $\begin{array}{c}\text { Encarcia: } \\
\text { whitefly }(1: 30)\end{array}$ & 25.7 & 32.4 & 27.3 & 22.7 & 14.2 & 12.4 \\
\hline 4 & $\begin{array}{c}\text { Pilarclotrin } \\
28 \% \text { ZC, (0.45 } \\
\text { 1/ha) (Etalon) }\end{array}$ & 27.8 & 5.3 & 0.4 & 6.4 & 14.5 & 23.7 \\
\hline 5 & Control & 29.1 & 33.1 & 38.6 & 44.3 & 51.8 & 58.2 \\
\hline \multicolumn{8}{|c|}{ Biologic efficiency } \\
\hline 6 & $\begin{array}{c}\text { Encarcia: } \\
\text { whitefly }(1: 10)\end{array}$ & 28.4 & - & - & $\begin{array}{l}42.2 \pm 0 . \\
5 \\
\end{array}$ & $\begin{array}{c}70.0 \pm 0 . \\
4\end{array}$ & $87.9 \pm 0.8$ \\
\hline 7 & $\begin{array}{c}\text { Encarcia: } \\
\text { whitefly }(1: 20)\end{array}$ & 26.3 & - & - & $\begin{array}{c}28.8 \pm 0 . \\
6\end{array}$ & $\begin{array}{l}57.0 \pm 0 . \\
2\end{array}$ & $64.2 \pm 0.5$ \\
\hline 8 & $\begin{array}{c}\text { Encarcia: } \\
\text { whitefly }(1: 30)\end{array}$ & 25.7 & - & - & $\begin{array}{c}11.6 \pm 0 . \\
2\end{array}$ & $\begin{array}{c}44.7 \pm 0 . \\
6\end{array}$ & $51.7 \pm 0.3$ \\
\hline 9 & Pilarclotrin & 27.8 & $80.9 \pm$ & $98.6 \pm$ & $76.9 \pm 0$. & $47.8 \pm 0$. & $14.7 \pm 0.6$ \\
\hline
\end{tabular}




\begin{tabular}{|c|c|c|c|c|c|c|c|}
\hline & $\begin{array}{c}28 \% \text { ZC, }(0.45 \\
1 / \text { ha) (Etalon) }\end{array}$ & & 0.4 & 0.8 & 5 & 3 & \\
\hline 10 & Control & 29.1 & - & - & - & - & - \\
\hline
\end{tabular}

The biological efficacy of Pilarclotrine $28 \% \quad \mathrm{ZC}$ as a benchmark was $47.8 \%$ (phytoplankton average 14.5 per leaf) on day 21 compared to phytophagous. Experiments have also shown that the biological effectiveness of enkarsia ( $E$ partenopea) against whiteflies over a period of time, and controls the amount of pest. In order to continue the research in the open field, a cucumber crop was conducted in Syrdarya province. Enkarsia was used in various proportions. During the application period, laboratory-grown enkarsia mushrooms were applied in ratios of 1:10, 1:20, 1:30 (parasite: host) to the developmental offspring of whitefly.

The results showed that when applied at a ratio of 1:10, the biological efficiency was $34.3 \%$ after 12 days, $62.5 \%$ after 18 days, and $83.5 \%$ after 24 days. At 30 days after application, $86.5 \%$ biological efficacy was maintained.

Relative air humidity and air temperature were also taken into account during the application of the encapsulation. According to him, the daytime temperature was $+26^{\circ} \mathrm{C}$, relative humidity was $55-60 \%$. When enkarsia was distributed at a ratio of $1: 20$ in the applied area, the biological efficiency increased to $22.4 \%$ on day $12,54.4 \%$ on day 18 , and parasites on day 24 , controlling the number of whiteflies to $61.8 \%$. On day 30 , up to $62.8 \%$ biological efficacy was detected and the amount of whitefly was controlled. Also, the highest rate in this variant was $62.8 \%$, after which the amount of leachate began to increase again. In the variant in which Encarsia was used at a ratio of 1:30, the figures were even lower. Biological efficacy was determined to be $18.2 \%$ on day $12,42.2 \%$ on day 18 , and $54.3 \%$ on day 24 . On day 30 , the biological efficiency decreased and was found to be $39.5 \%$ (Figure 2).

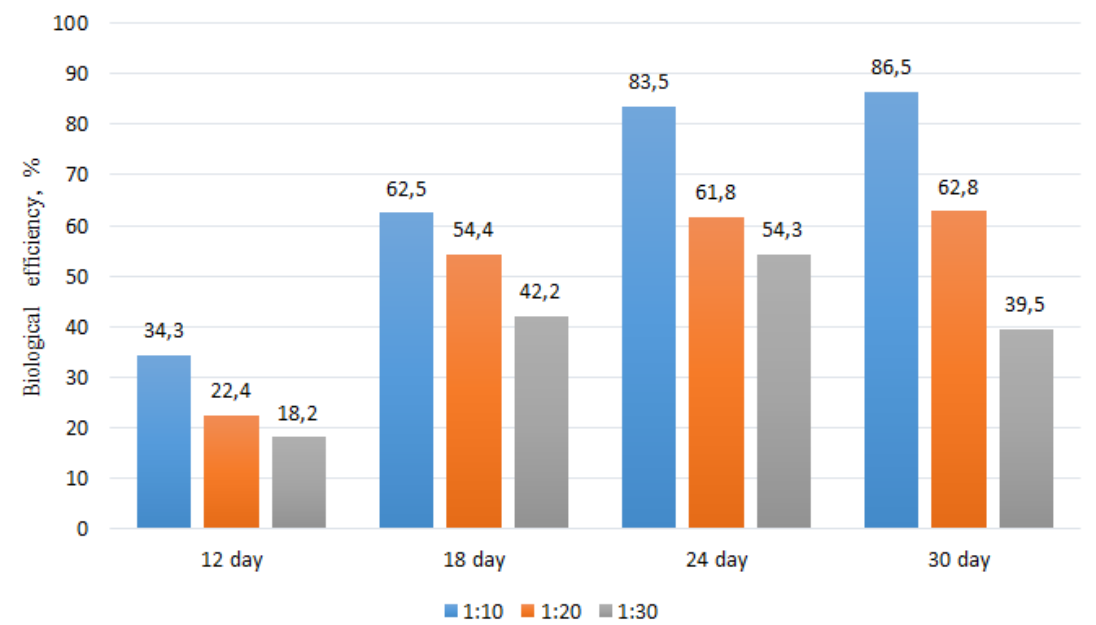

Fig. 2. Effectiveness of encarcation against greenhouse whitefly in cucumbers in open conditions (Syrdarya province, 2019-2020)

In this process, it became clear that the lower the incarceration parasite relative to the host, the higher their fertility and reproduction rate. Due to the increase in air temperature during the summer months, it took 65-80 days from transplanting the fodder plant seedlings to harvesting the plant to increase the encarche. However, during this period the amount of encarcation decreases. In the fall and winter months, this period was a little longer, reaching 
75 to 95 days. During the period of increase in air temperature in the development of greenhouse runoff, the rate of reproduction decreases slightly in June-July.

Enkarsia is separated from the natural "mother" form, and when the amount of whitefly is low, it is applied to the plants three times at intervals of 10 days, choosing the rate of consumption in relation to the stages of development of whitefly. After that, the enkarsia regulated the amount of alkalinity for 3-4 months. When the amount of whitefly was high, the encarcia was released into the crops once every 3 days, in a ratio of 1:10. Images or sponges of the parasite can be used during the application process. The results show that it can be managed under such conditions, but the sharp rise in air temperature has led to unfavorable conditions for parasite species.

\section{Conclusion}

When the formation of parasitic-host relationships with Encarsia formosa type greenhouse whitefly was studied, the period with the largest population in August averaged 31.5 per larvae, larvae 21.5, and fungi 17.1 per adult. In Encarsia partenopea, the maximum number of imagoes was 20.2. According to the results of the study, 27 species of entomophagous species belonging to 7 families of entomophagous species of whiteflies were identified. These are species of the families Neuroptera, Aphelinidae, Syrphidae, Coccinellidae, Anthocoridae, Nabidae, and Miridae. In the study of entomophagous species in the agrobiocenosis of greenhouse whitefly, the Shrysopidae family had an average population density of $32.6 \%$, Coccinellidae was $16.2 \%$, and the ladybug species was relatively common in this family - 4\%. Aphelinidae members of this family averaged $24.3 \%$, and a relatively common species was found to be enkarsia formosa, while a representative of the Phytoseiidae family of wild canes was found to be $14.8 \%$, a smaller number than other species.

\section{References}

1. KH. Kimsanbaev, M. Rashidov, B. Sulaymonov, J. Plant Protection and Quarantine 1, 27 (2011)

2. D. Gerling, O. Alomar, J. Arno, Crop Prot. 20, 779-799 (2001)

3. S. Li, X. Xue, M. Ahmed, S. Ren, Y. Du, J. Wu, A. Cuthbertson, B. Qui, Insect Science 18, 101-120 (2011)

4. M. de Oliveira, E. Amancio, R. Laumann, L. Gomes, Neotropical Entomology 32(1), 151-154 (2003)

5. J. Martin, L. Mound, Zootaxa 1492, 1-84 (2007)

6. S. Naranjo, L. Canias, P. Ellsworth, Hort. Internacional 43, 14-21 (2004)

7. L. Torres, A. Lourencao, V. Costa, B. Souza, M. Costa, R. Tanque, Neotropical Entomology 43, 189-191 (2014)

8. B. Sulaymonov, Solid State Technology 63(4), 19-28 (2020)

9. L. Kaiser, P. Ode, S. van Nouhuys, P. A. Calatayud, S. Colazza, A. M. Cortesero, J. van Baaren, Advances in Botanical Research 81, 179-223 (2017)

10. L. L. Vazquez, In Natural Enemies of Insect Pests in Neotropical Agroecosystems, 161-171 (2019) 